\title{
Role of epithelial chemokines in the pathogenesis of airway inflammation in asthma (Review)
}

\author{
CHI LIU ${ }^{1}$, XUN ZHANG ${ }^{1}$, YANG XIANG ${ }^{1}$, XIANGPING QU ${ }^{1}$, HUIJUN LIU ${ }^{1}$, \\ CAIXIA LIU ${ }^{1}$, MEILING TAN ${ }^{1}$, JIANXIN JIANG ${ }^{2}$ and XIAOQUN QIN ${ }^{1}$ \\ ${ }^{1}$ Department of Physiology, Xiangya School of Medicine, Central South University, \\ Changsha, Hunan $410008 ;{ }^{2}$ State Key Laboratory of Trauma, Institute of Surgery Research, \\ Third Military Medical University, Chongqing 400042, P.R. China
}

Received September 18, 2017; Accepted February 23, 2018

DOI: $10.3892 / \mathrm{mmr} .2018 .8739$

\begin{abstract}
As the first barrier to the outside environment, airway epithelial cells serve a central role in the initiation and development of airway inflammation. Chemokines are the most direct and immediate cell factors for the recruitment and migration of inflammatory cells. The present review focused on the role of epithelial chemokines in the pathogenesis of airway inflammation in asthma. In addition to traditional CC family chemokines and CXC family chemokines, airway epithelial cells also express other chemokines, including thymic stromal lymphopoietin and interleukin-33. By expressing and secreting chemokines, airway epithelial cells serve a key role in orchestrating airway inflammation in asthma.
\end{abstract}

\section{Contents}

1. Introduction

2. Expression properties of epithelial chemokines

3. Functional properties of chemokines and association between chemokines and asthma

4. Conclusion

\section{Introduction}

Airway inflammation has been regarded as the most important pathological characteristic of asthma patients (1). Infiltration of various inflammatory cells into the airway submucosa is also the basis of airway hyper-responsiveness (AHR) and airway remodeling (2). It has been verified that the development of chronic airway inflammation in asthma is due to

Correspondence to: Professor Xiaoqun Qin, Department of Physiology, Xiangya School of Medicine, Central South University, 110 Xiangya Road, Changsha, Hunan 410008, P.R. China

E-mail: liuchi7669@gmail.com

Key words: CC chemokines, CXC chemokines, thymic stromal lymphopoietin, airway epithelial cell, asthma inappropriate airway immune responses to specific pathogens or allergens from the outside environment (3). A disrupted immune response of airway epithelial cells induces the occurrence and development of complicated airway inflammation in asthma $(4,5)$. As they are situated between the host and the outside environment, airway epithelial cells are the physical defense line against microorganisms, gases and allergens. In recent years, the structural and functional homeostasis of airway epithelial cells in asthma pathogenesis has attracted increasing attention $(5,6)$. Airway epithelial cells rapidly identify and respond to microbes, tissue damage or cellular stress via expression of pattern recognition receptors (PRRs). Epithelial PRR activation then leads to the release of cytokines, chemokines and antimicrobial peptides, which further attract and activate innate and adaptive immune cells $(7,8)$. Notably, an increasing number of studies have confirmed that multiple pro-inflammatory mediators (including cytokines and chemokines) serve a major role in the recruitment and invasion of airway inflammatory cells $(7,9,10)$.

Chemokines are the most direct and immediate cell factors that selectively induce the migration of specific inflammatory cells by binding with different receptors (11). They are a group of low molecular weight (mostly 8-10 KDa) polypeptides that are designated for their targeted cell chemotaxis. There are four conserved cysteines in the protein structure of chemokine molecules. Chemokines are divided into the following four families (CC, CXC, $\mathrm{C}$ and CX3C) based on where other amino acids are inserted between the first two cysteines near the $\mathrm{N}$-terminus (12). By interacting with corresponding receptors, chemokines strongly contribute to the chemotaxis of neutrophils, eosinophils, basophils, monocytes, mast cells, dendritic cells (DCs), natural killer (NK) cells, T lymphocytes and B lymphocytes. There is not a simple one-to-one correspondence between chemokines and chemokine receptors. One chemokine receptor can be activated by different chemokines and one chemokine can bind to different chemokine receptors (13). The CC family contains $\sim 28$ types of chemokines with strong chemotaxis effects on almost all inflammatory cells (except neutrophils). The CXC chemokine family contains more than 15 types of chemokines, which possess potent effects on the recruitment of neutrophils and monocytes. Besides these four traditional cytokine families, there is a growing 
number of cytokines showing strong chemotactic effects which are also classified as chemokines $(14,15)$. Studies have shown that a variety of cells are involved in expression and secretion of chemokines, including macrophages, monocytes, eosinophils, basophils, neutrophils, mast cells, DCs and lymphocytes $(10,11,13)$. The participation of a variety of effector cells leads to the cascade of events triggering the activation of diverse immune responses. It has been identified that airway epithelial cells act as the key orchestrator to airway inflammation in asthma (16). Airway epithelial cells selectively produce a number of different chemokines that can induce various types of inflammatory cells which would release a variety of inflammatory factors. Such inflammatory factors cause the immediate phase reaction of airway inflammation mediated by immunoglobin ( $\operatorname{IgE})$ and induce chronic persistence airway inflammation with eosinophils and $\mathrm{T}$ helper cell (Th)2 lymphocytes $(9,17)$. The present review focused on the expression and biological characteristics of chemokines in airway epithelial cells and the role of these epithelial chemokines in the pathogenesis of airway inflammation in asthma (Table I).

\section{Expression properties of epithelial chemokines}

For airway epithelial cells, the expression of chemokines is regulated at several levels. Different expression properties of chemokines from diverse research models all indicate the importance of chemokines during the pathogenesis of airway inflammation in asthma (18).

Expression properties of CC family chemokines in airway epithelium. The early immune response is mediated mainly by inflammatory cytokines interleukin (IL)- 1 and tumor necrosis factor- $\alpha(\mathrm{TNF}-\alpha)$. It has been reported that IL- $1 \beta$ and TNF- $\alpha$ are present in the epithelial environment within hours of infection $(19,20)$. IL-1 $\beta$ and TNF- $\alpha$ then induce the expression of chemokines in epithelial cells (11). It has previously been demonstrated that TNF- $\alpha$ stimulates the expression of $\mathrm{C}-\mathrm{C}$ motif chemokine ligands CCL2, CCL4, CCL5, CCL11 and CCL20. Furthermore, airway epithelial cells release CCL5 and CCL20 upon stimulation by IL-1 $\beta$ (18). IL-1 $\beta$ can also induce the expression of CCL3 and CCL4 in airway epithelial cells by activating nuclear factor $(\mathrm{NF})-\kappa \mathrm{B}$. In addition, $\mathrm{NF}-\kappa \mathrm{B}$ also activates transcription of the gene encoding CCL2 as its promoter contains an NF- $\mathrm{B}$ binding site $(21,22)$.

Several other inflammatory cytokines can induce the expression of certain chemokines. Previous studies have revealed that TNF- $\alpha$ in combination with IL- 4 or IL-13 upregulates the expression and secretion of CCL17 in epithelial cells $(23,24)$. It has also been indicated that CCL11 and CCL20 are produced following IL-4 or IL-13 stimulation (25). Furthermore, it has been demonstrated that clusterin induces the production of CCL20 by regulating the oxidative stress environment in airway epithelial cells from mice studies (26). Previous studies have demonstrated that microRNA-34a, 15-lipoxygenase and histamine are important regulators for CCL22 in airway epithelial cells (27-29).

In addition, airway epithelial cells produce chemokines in response to immunological environmental factors including microbial and viral stimuli (11). Viral or bacterial infection induces the secretion of high levels of CCL2, CCL5 and CCL20 by airway epithelial cells (30). Furthermore, infection by viruses increases CCL5 expression in different types of cells. For example, respiratory syncytial virus infection results in enhanced expression of CCL5 in human nasal mucosa and gland epithelial cells, and infection by influenza virus induces CCL5 expression in human bronchial tissues and nasal polyp epithelial cells (31). In addition, Der $\mathrm{p}$ allergens from house dust mites induce CCL17 expression in bronchial epithelial cells which appears to be mediated by a disintegrin and metalloproteinase-dependent phosphorylation of epidermal growth factor receptor and subsequent activation of mitogen-activated protein kinase (MAPK) and NF- $\mathrm{BB}(32)$.

Expression properties of CXC family chemokines in airway epithelium. It has been demonstrated that IL-17 promotes the expression of CXCL1 and CXCL5 in bronchial epithelial cells and that IL-17 potentially promotes CXCL1 expression mainly through the extracellular regulated protein kinases (ERK) or MAPK pathway (33). At the same time, different cytokines stimulate CXCL8 secretion under the control of different signaling pathways, including NF- $\mathrm{B}, \mathrm{ERK}$, c-Jun N-terminal kinase (JNK) and MAPK pathways (34). Additionally, Janus kinase (JAK) and the synergistic effect of TNF- $\alpha$ and interferon- $\gamma$ can induce CXCL10 expression in airway epithelial cells (35). On this basis, these associated signaling molecules have also been used as potential targets of anti-inflammatory treatment. It has been identified that the inhibition of JAK pathway in the airway epithelium may provide an alternative anti-inflammatory approach to glucocorticosteroid-resistant diseases in vitro (36). It has also been observed that the long-acting $\beta 2$ agonists downregulate poly I:C-induced CXCL10 expression in bronchial epithelial cells via the $\beta 2$ adrenoreceptor-cyclic adenosine monophosphate and JNK pathways in vitro (37).

Expression properties of other chemokines in airway epithelium. Various cytokines including thymic stromal lymphopoietin (TSLP) and IL-33 secreted by airway epithelial cells have previously been identified to possess very strong recruitment effects on inflammatory cells. They are also classified as chemokines not belonging to the traditional four classic chemokine families $(38,39)$.

Previous studies have revealed that TNF- $\alpha$ and IL-1 $\beta$ can induce the expression of IL-33 (40). Park et al (41) verified that TNF- $\alpha$ stimulates IL-33 expression in primary nasal epithelial cells and A549 cells via the NF- $\mathrm{BB}$, ERK and MAPK pathways in vitro. Furthermore, IL-33 has been reported to induce the production of TSLP in bronchial epithelial cells following activation by antigens (42). Respiratory syncytial virus infection can also rapidly transfer stress signals through the JNK and MAPK pathways via direct stimulation of epithelial cells to upregulate expression of TSLP (43).

\section{Functional properties of chemokines and associations between chemokines and asthma}

Effect of chemokines on DCs and T cells. Recruitment of Th2 cells and the subsequent production of Th2-type cytokines form the main characteristics of asthma airway inflammation (44). 


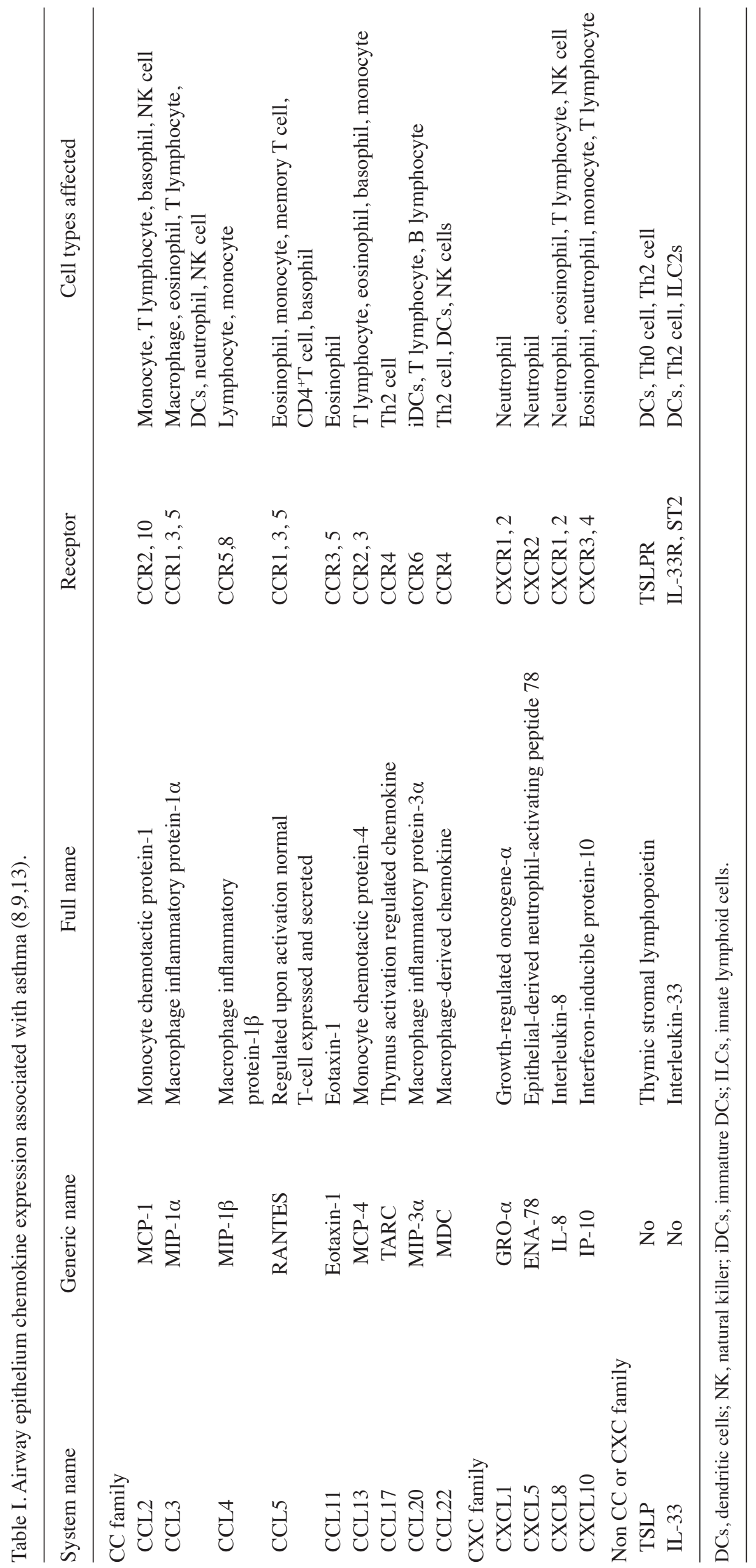




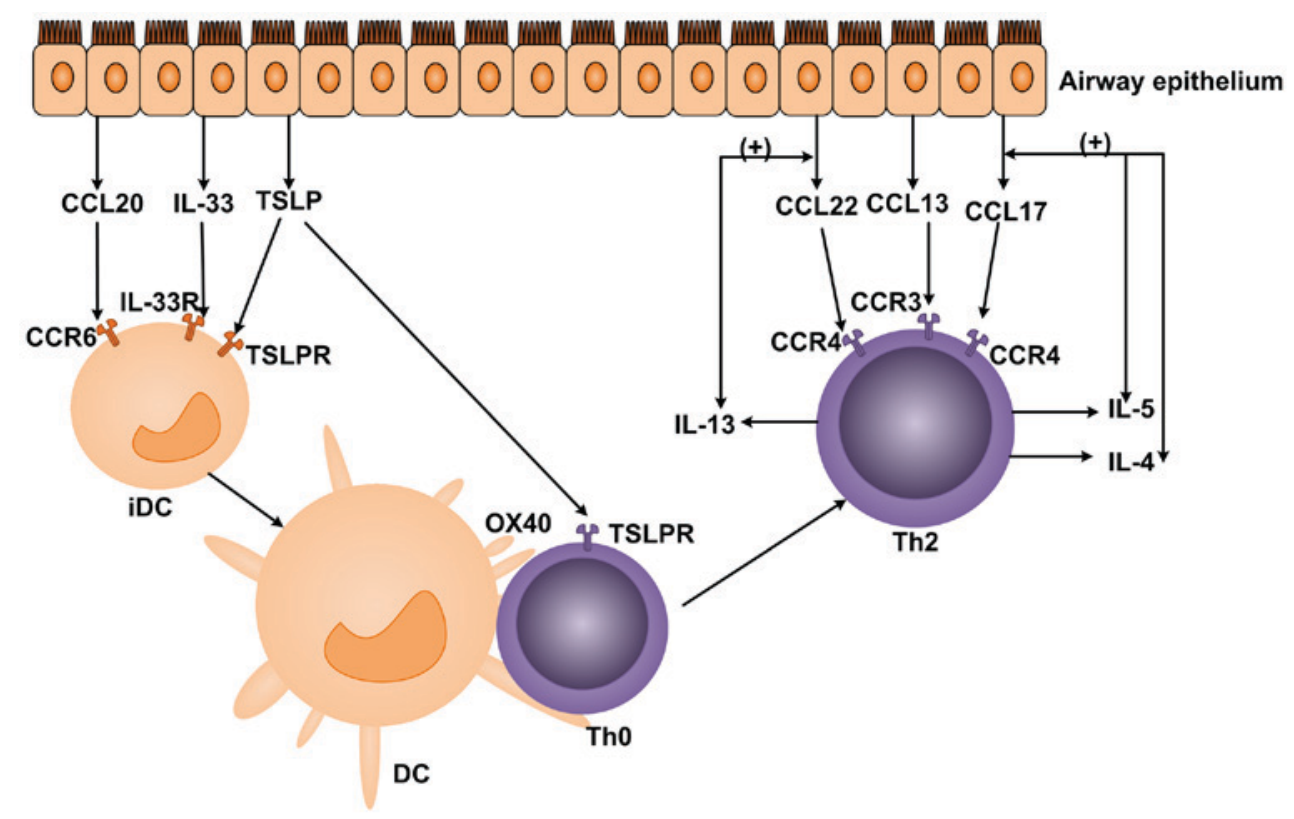

Figure 1. The effect of chemokines on DCs and T cells. CCL20, IL-33 and TSLP secreted by airway epithelial cells combine with CCR6, IL-33R and TSLPR on iDCs to serve a role in chemotaxis. CCL13, CCL17 and CCL22 combine with CCR3 and CCR4 on Th2 cells to induce chemotaxis. DCs, dendritic cells; CCL, C-C motif chemokine ligand; IL, interleukin; TSLP, thymic stromal lymphopoietin; CCR, C-C chemokine receptor; IL-33R, IL-33 receptor; TSLPR, TSLP receptor.

DCs are sentinels of the adaptive immune system as they can induce the differentiation of Th2 cells. The key role of DCs in asthma pathogenesis has been a subject of attention for more than 15 years (1).

In the pathogenesis of asthma, the secretion of CCL20, IL-33 and TSLP is substantially increased following stress by allergens and other pathogenic substances. C-C chemokine receptor CCR6, IL-33R and TSLPR (corresponding receptors for CCL20, IL-33 and TSLP respectively) are expressed on immature DCs (iDCs). By binding with these receptors, CCL20, IL-33 and TSLP activate iDCs and promote their maturation $(26,42)$. DCs then migrate to the $\mathrm{T}$ cell zone in mediastinal lymph nodes, where they activate $\mathrm{T}$ cells via antigen presentation and co-stimulation. Furthermore, TSLP upregulates the expression of surface co-stimulatory molecules, including CD40, CD80 and CD86 on DCs. Under the influence of secreted cytokines and membrane-expressed molecules including OX40 L, Jagged1, IL-6 and leukotrienes $\mathrm{C} 4$, activated inflammatory $\mathrm{DCs}$ interact with naive $\mathrm{CD} 4^{+} \mathrm{T}$ cells and induce the differentiation of Th2, Th17 and follicular helper T cells $(45,46)$. CCR3 and CCR4 surface receptors of Th2 cells directly bind to chemokines secreted by epithelial cells. CCR4 interacts with CCL17/CCL22, and CCR3 interacts with CCL13 (27). Animal studies have indicated that targeted blocking of CCR4/CCR3 receptors can significantly reduce the eosinophil ratio in the bronchoalveolar lavage fluid of asthmatic model mice (47). Following prompting by the actions of these chemokines, Th2 cells infiltrate into the site of inflammation where they secrete cytokines including IL-4, IL-5, IL-13 and TNF- $\alpha$ (Fig. 1). These cytokines in turn cause enhanced airway mucus secretion and airway epithelial structure destruction, further provoking airway inflammation and AHR $(48,49)$. IL-4 induces B cell activation and the secretion of IgE; IL-13 causes goblet cell metaplasia, AHR and increases the expression of adhesion molecules on vascular endothelial cells (44,50). Furthermore, IL-4 and IL-13 can also promote the secretion of CCL17 by airway epithelial cells, and IL-13 can promote the secretion of CCL22 (23). These chemokines, which result from cascade amplification, further induce the aggregation of Th2 cell infiltration. The specific enhanced expression of TSLP in airway epithelial cells results in initial $\mathrm{CD} 4{ }^{+} \mathrm{T}$ lymphocyte proliferation and Th2 cell differentiation (38). Conversely, targeting TSLP with short hairpin RNA or antibodies, alleviates airway inflammation and decreases epithelial CCL17 in a murine model of asthma $(51,52)$.

Effect of chemokines on eosinophils, neutrophils and innate lymphoid cells (ILC)2. In addition to activated DCs and Th2 cells, eosinophils also act as key effector cells in the airway inflammation of asthma. The invasion of eosinophils in the airway is closely associated with the severity of asthma (53). Eosinophils initially form in the bone marrow and differentiate from progenitor cells. By rolling adhesion and exudation, eosinophils interact with endothelial cells. Eosinophils are activated to release granule-associated proteins, which cause airway epithelial injury, smooth muscle contraction, inflammatory cell infiltration and AHR (54). In this process, CCL5 and CCL11 function as potent eosinophil chemoattractants by binding to CCR3 (Fig. 2). CCL11 also induces eosinophil chemotaxis via the activation of ERK and MAPK pathways (55). CXCL8 and CXCL10 can also bind to CXCR2 and CXCR3, respectively, on eosinophils to induce the recruitment of eosinophils. Following the recruitment to the airway inflammation area, eosinophils release various inflammatory mediators and toxic proteins (including eosinophil cationic protein, myelin basic protein, palmitic acid and IL-5 which further aggravate airway inflammation. Eosinophils also produce protein particles to cause tissue damage (56) and respiratory burst $(57,58)$. 


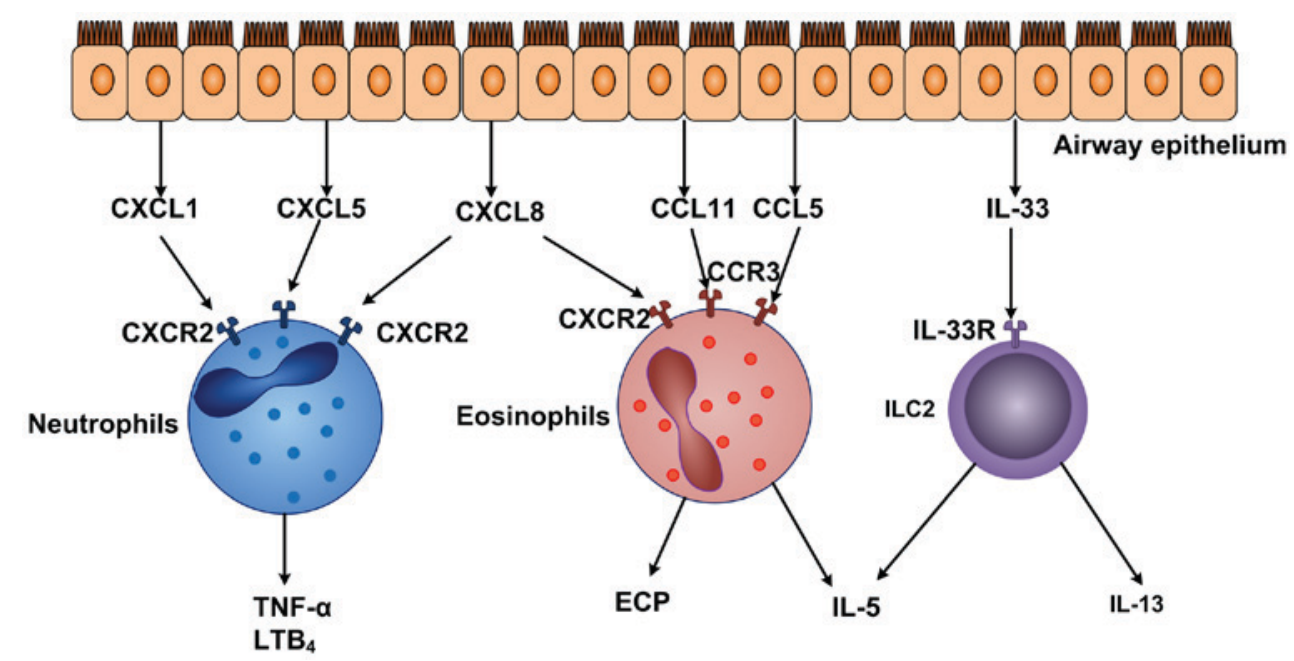

Figure 2. The effect of chemokines on eosinophils, neutrophils and ILC2. CXCL1, CXCL5 and CXCL8 secreted by airway epithelial cells combine with CXCR2 on neutrophils to serve a role in chemotaxis. CCL5, CCL11 and CXCL8 combine with CCR3 and CXCR2 on eosinophils to induce chemotaxis. IL-33 combine with IL-33R on ILC2 to induce the activation of ILC2. ILC, innate lymphoid cell; R, receptor; CCR, C-C chemokine receptor; IL, interleukin.

Although asthma is classically associated with eosinophilia and Th2 cytokines, certain asthma patients exhibit a neutrophil-predominant phenotype without evident Th2 cytokines. CXCL8 and CXCL10 possess a strong chemotactic effect on neutrophils (Fig. 2). Takaku et al (58) identified that CXCL10 and CXCL8 are elevated in asthma phenotypes with increasing eosinophils and neutrophils in airways. In addition, CXCL8, CXCL1 and CXCL5 can bind to CXCR2 (a specific surface receptor on neutrophils), which can activate neutrophils and attract them to inflammation sites. These chemokines also promote expression of adhesion molecules, (including CD11a, -b, -c and CD18) and cause cell deformation, eosinophil degranulation and respiratory burst (59-61). In addition, TNF- $\alpha$, leukotriene B4 and other inflammatory mediators produced by activated neutrophils further exacerbate airway inflammation, leading to airway submucosal edema and goblet cell metaplasia (62).

An increasing number of studies have demonstrated that ILC2 $\mathrm{s}$ contribute to the initiation and maintenance of the adaptive Th2 immune response $(63,64)$. By binding to IL-33R on ILC2 cells, IL-33 promotes production of IL-5 and IL-13 by ILC2 (Fig. 2). IL-13 secreted by ILC2 cells can bind to IL-13R on macrophages, which further induce the activation of macrophages (65). In addition, early eosinophilia in the lung is driven by IL-5 that also supports the development of eosinophils in the bone marrow. Consequently, ILC2 cells contribute to Th2 cell-mediated lung inflammation in the pathogenesis of asthma (66).

Effect of chemokines on monocytes. Monocytes express specific high-affinity receptors for CCL2, CXCL10, CCR2 and CXCR3 (9). Macrophage recruitment occurs via a chemotactic gradient of monocyte selective chemokines. Following activation and recruitment, monocytes release superoxide anions and lysozymes (67). At the same time, surface-specific adhesion molecules CD11c and CD11b are expressed on monocytes, which are involved in the regulation of airway inflammation. In addition, the increased expression of integrin $\beta 2$ and $\alpha 4$ is accompanied by upregulated IL-1 and IL-6 (68). Interactions between mucosal epithelial cells and macrophages are pivotal to allergic lung inflammation. Increased expression of CCL2 has been reported in asthmatic airway epithelial cells, blocking the CCL2-CCR2 axis and attenuating the asthma phenotype in other animal models of asthma (69).

\section{Conclusion}

The airway immune response is mediated by airway epithelial cells through the secretion of chemokines. First, chemokines selectively induce various inflammatory cells to accumulate directly at the site of inflammation. Chemokines further induce stromal and inflammatory cells and produce more chemokines, resulting in a cascade effect that results in more severe tissue damage indirectly. The present review provides novel considerations for asthma airway inflammation research from a chemokine perspective, and a fresh approach to the clinical therapy of asthma.

\section{Acknowledgements}

Not applicable.

\section{Funding}

This review was funded by grants from the National Natural Science Foundation of China (grant nos. 81270065, 81370116, 81570026,81670002 and 3167188), the Hunan Natural Science Foundation (grant nos. 2013JJ4030, 2015JJ3170, 2015JJ2147 and 2017JJ2402), the National Basic Research Program of China (973 Program; grant no. 2012CB518104), the Open Foundation of Hunan College Innovation Program (grant nos. 16K097 and 14K109) and the Youth Support Program of China Science Communication and the Fundamental Research Funds for the Central Universities of Central South University [grant no. 45 (2015)].

\section{Availability of data and materials}

Not applicable. 


\section{Authors' contributions}

ChL and XQ conceived and designed this review. XZ, YX, XQ and HL collected the relevant papers. CL, MT and JJ obtained and analyzed the relevant data from the references. ChL wrote the review.

\section{Ethics approval and consent to participate}

Not applicable.

\section{Consent for publication}

Not applicable.

\section{Competing interests}

The authors declare that they have no competing interests.

\section{References}

1. Ishmael FT: The inflammatory response in the pathogenesis of asthma. J Am Osteopath Assoc 111 (11 Suppl 7): S11-S17, 2011.

2. KleinJan A: Airway inflammation in asthma: Key players beyond the Th2 pathway. Curr Opin Pulm Med 22: 46-52, 2016.

3. Papi A, Brightling C, Pedersen SE and Reddel HK: Asthma. Lancet 391: 783-800, 2017.

4. Tang D, Kang R, Xiao W, Wang H, Calderwood SK and Xiao X: The anti-inflammatory effects of heat shock protein 72 involve inhibition of high-mobility-group box 1 release and proinflammatory function in macrophages. J Immunol 179: 1236-1244, 2007.

5. Hallstrand TS, Hackett TL, Altemeier WA, Matute-Bello G, Hansbro PM and Knight DA: Airway epithelial regulation of pulmonary immune homeostasis and inflammation. Clin Immunol 151: 1-15, 2014.

6. Holgate ST: The sentinel role of the airway epithelium in asthma pathogenesis. Immunol Rev 242: 205-219, 2011.

7. Mitchell PD and O'Byrne PM: Epithelial-derived cytokines in asthma. Chest 151: 1338-1344, 2017.

8. Gao W, Li L, Wang Y, Zhang S, Adcock IM, Barnes PJ, Huang M and Yao X: Bronchial epithelial cells: The key effector cells in the pathogenesis of chronic obstructive pulmonary disease? Respirology 20: 722-729, 2015.

9. Erle DJ and Sheppard D: The cell biology of asthma. J Cell Biol 205: 621-631, 2014.

10. Mitchell PD and O'Byrne PM: Biologics and the lung: TSLP and other epithelial cell-derived cytokines in asthma. Pharmacol Ther 169: 104-112, 2017.

11. Smit JJ and Lukacs NW: A closer look at chemokines and their role in asthmatic responses. Eur J Pharmacol 533: 277-288, 2006.

12. Castan L, Magnan A and Bouchaud G: Chemokine receptors in allergic diseases. Allergy 72: 682-690, 2017.

13. Guerreiro R, Santos-Costa Q and Azevedo-Pereira JM: The chemokines and their receptors: Characteristics and physiolog ical functions. Acta Medica Portuguesa 24 (Suppl 4): S967-S976, 2011.

14. Fall N, Bove KE, Stringer K, Lovell DJ, Brunner HI, Weiss J, Higgins GC, Bowyer SL, Graham TB, Thornton S and Grom AA: Association between lack of angiogenic response in muscle tissue and high expression of angiostatic ELR-negative CXC chemokines in patients with juvenile dermatomyositis: possible link to vasculopathy. Arthritis Rheum 52: 3175-3180, 2005.

15. Osei-Kumah A, Wark PA, Smith R and Clifton VL: Asthma during pregnancy alters immune cell profile and airway epithelial chemokine release. Inflamm Res 59: 349-358, 2010.

16. Iosifidis T, Garratt LW, Coombe DR, Knight DA, Stick SM and Kicic A: Airway epithelial repair in health and disease: Orchestrator or simply a player? Respirology 21: 438-448, 2016.

17. Fuke S, Betsuyaku T, Nasuhara Y, Morikawa T, Katoh $\mathrm{H}$ and Nishimura M: Chemokines in bronchiolar epithelium in the development of chronic obstructive pulmonary disease. Am J Respir Cell Mol Biol 31: 405-412, 2004.
18. Post S, Rozeveld D, Jonker MR, Bischoff R, van Oosterhout AJ and Heijink IH: ADAM10 mediates the house dust mite-induced release of chemokine ligand CCL20 by airway epithelium. Allergy 70: 1545-1552, 2015

19. Julkunen I, Melen K, Nyqvist M, Pirhonen J, Sareneva T and Matikainen S: Inflammatory responses in influenza A virus infection. Vaccine 19 (Suppl 1): S32-S37, 2000.

20. van de Veerdonk FL, Netea MG, Dinarello CA and Joosten LA: Inflammasome activation and IL-1beta and IL-18 processing during infection. Trends Immunol 32: 110-116, 2011.

21. Zhang Z, Bryan JL, DeLassus E, Chang LW, Liao W and Sandell LJ: CCAAT/enhancer-binding protein beta and NF- $\kappa B$ mediate high level expression of chemokine genes CCL3 and CCL4 by human chondrocytes in response to IL-1 $\beta$. J Biol Chem 285: 33092-33103, 2010.

22. Hu WT, Li MQ, Liu W, Jin LP, Li DJ and Zhu XY: IL-33 enhances proliferation and invasiveness of decidual stromal cells by up-regulation of CCL2/CCR2 via NF- $\mathrm{BB}$ and ERK1/2 signaling. Mol Hum Reprod 20: 358-372, 2014

23. Faffe DS, Whitehead T, Moore PE, Baraldo S, Flynt L, Bourgeois K, Panettieri RA and Shore SA: IL-13 and IL-4 promote TARC release in human airway smooth muscle cells: Role of IL-4 receptor genotype. Am J Physiol Lung Cell Mol Physiol 285: L907-L914, 2003.

24. Hijnen D, De Bruin-Weller M, Oosting B, Lebre C, De Jong E, Bruijnzeel-Koomen C and Knol E: Serum thymus and activation-regulated chemokine (TARC) and cutaneous T cell-attracting chemokine (CTACK) levels in allergic diseases: TARC and CTACK are disease-specific markers for atopic dermatitis. J Allergy Clin Immunol 113: 334-340, 2004

25. Zhou X, Hu H, Balzar S, Trudeau JB and Wenzel SE: MAPK regulation of IL-4/IL-13 receptors contributes to the synergistic increase in CCL11/eotaxin- 1 in response to TGF- $\beta 1$ and IL-13 in human airway fibroblasts. J Immunol 188: 6046-6054, 2012.

26. Hong GH, Kwon HS, Moon KA, Park SY, Park S, Lee KY, Ha EH, Kim TB, Moon HB, Lee HK and Cho YS: Clusterin modulates allergic airway inflammation by attenuating CCL20-mediated dendritic cell recruitment. J Immunol 196: 2021-2030, 2016.

27. He M, Song G, Yu Y, Jin Q and Bian Z: LPS-miR-34a-CCL22 axis contributes to regulatory $\mathrm{T}$ cell recruitment in periapical lesions. Biochem Biophys Res Commun 460: 733-740, 2015.

28. Kimura S, Tanimoto A, Wang KY, Shimajiri S, Guo X, Tasaki T, Yamada S and Sasaguri Y: Expression of macrophage-derived chemokine (CCL22) in atherosclerosis and regulation by histamine via the $\mathrm{H} 2$ receptor. Pathol Int 62: 675-683, 2012.

29. Abrial C, Grassin-Delyle S, Salvator H, Brollo M, Naline E and Devillier P: 15-Lipoxygenases regulate the production of chemokines in human lung macrophages. Br J Pharmacol 172: 4319-4330, 2015

30. Schneider D, Hong JY, Bowman ER, Chung Y, Nagarkar DR, McHenry CL, Goldsmith AM, Bentley JK, Lewis TC and Hershenson MB: Macrophage/epithelial cell CCL2 contributes to rhinovirus-induced hyperresponsiveness and inflammation in a mouse model of allergic airways disease. Am J Physiol Lung Cell Mol Physiol 304: L162-L169, 2013.

31. Renois F, Jacques J, Talmud D, Deslée G, Lévêque N and Andréoletti L: Respiratory echovirus 30 and coxsackievirus B5 can induce production of RANTES, MCP-1 and IL-8 by human bronchial epithelial cells. Virus Res 152: 41-49, 2010.

32. Heijink IH, Marcel Kies P, van Oosterhout AJ, Postma DS, Kauffman HF and Vellenga E: Der p, IL-4 and TGF-beta cooperatively induce EGFR-dependent TARC expression in airway epithelium. Am J Respir Cell Mol Biol 36: 351-359, 2007.

33. Herjan T, Yao P, Qian W, Li X, Liu C, Bulek K, Sun D, Yang WP, Zhu J, He A, et al: HuR is required for IL-17-induced Act1-mediated CXCL1 and CXCL5 mRNA stabilization. J Immunol 191: 640-649, 2013.

34. Katanov C, Lerrer S, Liubomirski Y, Leider-Trejo L, Meshel T, Bar J, Feniger-Barish R, Kamer I, Soria-Artzi G, Kahani H, et al: Regulation of the inflammatory profile of stromal cells in human breast cancer: Prominent roles for TNF- $\alpha$ and the NF- $\kappa \mathrm{B}$ pathway. Stem Cell Res Therapy 6: 87, 2015.

35. Song Y, Lin Q, Zheng J, Zhu X and Yang S: PPAR- $\gamma$ agonist inhibits the expressions of chemokines induced by IFN- $\gamma$ and TNF- $\alpha$ in renal tubular epithelial cells. Xi Bao Yu Fen Zi Mian Yi Xue Za Zhi 30: 673-676, 2014 (In Chinese).

36. Fenwick PS, Macedo P, Kilty IC, Barnes PJ and Donnelly LE: Effect of JAK Inhibitors on Release of CXCL9, CXCL10 and CXCL11 from human airway epithelial cells. PLoS One 10: e0128757, 2015 . 
37. Chien JW, Chu YT, Yang SN, Kuo CH, Wang WL, Kuo PL, Jong YJ and Hung $\mathrm{CH}$ : Long-acting beta 2 agonists suppress IP-10 expression in human bronchial epithelial cells. J Investig Med 60: 1048-1053, 2012.

38. Takahashi N, Sugaya M, Suga H, Oka T, Kawaguchi M, Miyagaki T, Fujita $\mathrm{H}$ and Sato S: Thymic stromal chemokine TSLP acts through Th2 cytokine production to induce cutaneous T-cell lymphoma. Cancer Res 76: 6241-6252, 2016.

39. Prefontaine D, Nadigel J, Chouiali F, Audusseau S, Semlali A, Chakir J, Martin JG and Hamid Q: Increased IL-33 expression by epithelial cells in bronchial asthma. J Allergy Clin Immunol 125 752-754, 2010

40. Sei H, Oshima T, Shan J, Wu L, Yamasaki T, Okugawa T, Kondo T, Tomita T, Fukui H, Watari J and Miwa H: Esophageal epithelial-derived IL-33 Is upregulated in patients with heartburn. PLoS One 11: e0154234, 2016.

41. Park IH, Park JH, Shin JM and Lee HM: Tumor necrosis factor- $\alpha$ regulates interleukin-33 expression through extracellular signal-regulated kinase, p38 and nuclear factor- $\mathrm{kB}$ pathways in airway epithelial cells. Int Forum Allergy Rhinol 6: 973-980, 2016

42. Nygaard U, Hvid M, Johansen C, Buchner M, Fölster-Holst R, Deleuran M and Vestergaard C: TSLP, IL-31, IL-33 and sST2 are new biomarkers in endophenotypic profiling of adult and childhood atopic dermatitis. J Eur Acad Dermatol Venereol 30 1930-1938, 2016.

43. Golebski K, van Tongeren J, van Egmond D, de Groot EJ, Fokkens WJ and van Drunen CM: Specific Induction of TSLP by the Viral RNA Analogue Poly (I:C) in primary epithelial cells derived from nasal polyps. PLoS One 11: e0152808, 2016

44. Amin K: The Role of the T lymphocytes and remodeling in asthma. Inflammation 39: 1475-1482, 2016.

45. Froidure A, Vandenplas O, D'Alpaos V, Evrard G and Pilette C: Persistence of asthma following allergen avoidance is associated with proTh 2 myeloid dendritic cell activation. Thorax 70 : 967-973, 2015

46. Lin CL, Hsiao G, Wang CC and Lee YL: Corrigendum to 'Imperatorin exerts antiallergic effects in Th2-mediated allergic asthma via induction of IL-10-producing regulatory $\mathrm{T}$ cells by modulating the function of dendritic cells' [Pharmacol. Res. (2016) 111-121]. Pharmacological Res 124: 157, 2017.

47. Purandare AV, Wan H, Somerville JE, Burke C, Vaccaro W, Yang X, McIntyre KW and Poss MA: Core exploration in optimization of chemokine receptor CCR4 antagonists. Bioorg Med Chem Lett 17: 679-682, 2007.

48. Penaloza-MacMaster P, Kamphorst AO, Wieland A, Araki K, Iyer SS, West EE, O'Mara L, Yang S, Konieczny BT, Sharpe AH, et al: Interplay between regulatory T cells and PD-1 in modulating $\mathrm{T}$ cell exhaustion and viral control during chronic LCMV infection. J Exp Med 211: 1905-1918, 2014

49. Liao J, Liang G, Xie S, Zhao H, Zuo X, Li F, Chen J, Zhao M, Chan TM and Lu Q: CD40L demethylation in CD4(+) T cells from women with rheumatoid arthritis. Clin Immunol 145: 13-18, 2012.

50. Alasandagutti ML, Ansari MS, Sagurthi SR, Valluri V and Gaddam S: Role of IL-13 genetic variants in signalling of asthma. Inflammation 40: 566-577, 2017.

51. Chen YL and Chiang BL: Targeting TSLP With shRNA alleviates airway inflammation and decreases epithelial CCL17 in a murine model of asthma. Mol Ther Nucleic Acids 5: e316, 2016.

52. Wu J, Dong F, Wang RA, Wang J, Zhao J, Yang M, Gong W, Cui R and Dong L: Central role of cellular senescence in TSLP-induced airway remodeling in asthma. PLoS One 8: e77795, 2013.

53. Walsh CJ, Zaihra $T$, Benedetti $A$, Fugère $C$, Olivenstein R, Lemière C, Hamid Q and Martin JG: Exacerbation risk in severe asthma is stratified by inflammatory phenotype using longitudinal measures of sputum eosinophils. Clin Exp Allergy 46: $1291-1302,2016$
54. Rose CE Jr, Lannigan JA, Kim P, Lee JJ, Fu SM and Sung SS: Murine lung eosinophil activation and chemokine production in allergic airway inflammation. Cell Mol Immunol 7: 361-374, 2010.

55. Asosingh K, Vasanji A, Tipton A, Queisser K, Wanner N, Janocha A, Grandon D, Anand-Apte B, Rothenberg ME, Dweik $R$ and Erzurum SC: Eotaxin-rich proangiogenic hematopoietic progenitor cells and CCR3+ endothelium in the atopic asthmatic response. J Immunol 196: 2377-2387, 2016.

56. George L and Brightling CE: Eosinophilic airway inflammation: Role in asthma and chronic obstructive pulmonary disease. Ther Adv Chronic Dis 7: 34-51, 2016.

57. Kikuchi I, Kikuchi S, Kobayashi T, Hagiwara K, Sakamoto Y, Kanazawa $M$ and Nagata $M$ : Eosinophil trans-basement membrane migration induced by interleukin- 8 and neutrophils. Am J Respir Cell Mol Biol 34: 760-765, 2006.

58. Takaku Y, Nakagome K, Kobayashi T, Hagiwara K, Kanazawa M and Nagata M: IFN- $\gamma$-inducible protein of $10 \mathrm{kDa}$ upregulates the effector functions of eosinophils through beta 2 integrin and CXCR3. Respir Res 12: 138, 2011.

59. Henkels KM, Frondorf K, Gonzalez-Mejia ME, Doseff AL and Gomez-Cambronero J: IL-8-induced neutrophil chemotaxis is mediated by Janus kinase 3 (JAK3). FEBS Lett 585: 159-166, 2011.

60. Sawant KV, Xu R, Cox R, Hawkins H, Sbrana E, Kolli D, Garofalo RP and Rajarathnam K: Chemokine CXCL1-mediated neutrophil trafficking in the lung: Role of CXCR2 activation. J Innate Immu 7: 647-658, 2015.

61. Disteldorf EM, Krebs CF, Paust HJ, Turner JE, Nouailles G, Tittel A, Meyer-Schwesinger C, Stege G, Brix S, Velden J, et al: CXCL5 drives neutrophil recruitment in TH17-mediated GN. J Am Soc Nephrol 26: 55-66, 2015.

62. Mosca T, Menezes MC, Silva AV, Stirbulov R and Forte WC: Chemotactic and phagocytic activity of blood neutrophils in allergic asthma. Immunol Invest 44: 509-520, 2015.

63. Drake LY, Iijima K and Kita H: Group 2 innate lymphoid cells and CD4+ T cells cooperate to mediate type 2 immune response in mice. Allergy 69: 1300-1307, 2014.

64. Halim TY, Steer CA, Matha L, Gold MJ, Martinez-Gonzalez I, McNagny KM, McKenzie AN and Takei F: Group 2 innate lymphoid cells are critical for the initiation of adaptive T helper 2 cell-mediated allergic lung inflammation. Immunity 40: 425-435, 2014.

65. Zhu J: T helper 2 (Th2) cell differentiation, type 2 innate lymphoid cell (ILC2) development and regulation of interleukin-4 (IL-4) and IL-13 production. Cytokine 75: 14-24, 2015.

66. Molofsky AB, Van Gool F, Liang HE, Van Dyken SJ, Nussbaum JC, Lee J, Bluestone JA and Locksley RM: Interleukin-33 and interferon-gamma counter-regulate group 2 innate lymphoid cell activation during immune perturbation. Immunity 43: 161-174, 2015.

67. Wang J, Vodovotz Y, Fan L, Li Y, Liu Z, Namas R, Barclay D, Zamora R, Billiar TR, Wilson MA, et al: Injury-induced MRP8/MRP14 stimulates IP-10/CXCL10 in monocytes/macrophages. FASEB J 29: 250-262, 2015.

68. Carta S, Tassi S, Delfino L, Omenetti A, Raffa S, Torrisi MR, Martini A, Gattorno M and Rubartelli A: Deficient production of IL-1 receptor antagonist and IL-6 coupled to oxidative stress in cryopyrin-associated periodic syndrome monocytes. Ann Rheum Dis 71: 1577-1581, 2012.

69. Mellado M, Martin de Ana A, Gomez L, Martinez C and Rodriguez-Frade JM: Chemokine receptor 2 blockade prevents asthma in a cynomolgus monkey model. J Pharmacol Exp Ther 324: 769-775, 2008. 